\title{
Triaxial Strength of Concrete Materials
}

\author{
Kaspar J. Willam*
}

\section{Opening}

The triaxial strength of concrete materials plays a central role for the assessment of safety of reinforced and prestressed concrete structures. In fact, strength criteria are at the core of elastic service load analysis when the safety factor of allowable stress design assures a safe distance of the stress state from the failure envelope. To this end traditional failure criteria impose constraints on the stress, strain or energy storage capacity of the material, which may be interpreted geometrically in the form of an envelope condition. Along similar vanes, LRFD design concepts resort to failure envelopes in the form of yield functions which delimit the strength of the material, although there is a need to characterize the deformation capacity, especially in ductility based design such as in earthquake engineering. In short, the notion of a failure envelope is central to modern design, and reliability-based safety assessments.

\section{Historical Remarks}

The following remarks concentrate on events which led to the development of the so-called 'Five Parameter Model' for the triaxial strength of concrete which was developed in the early 1970's for the Iimit load assessment of prestressed concrete nuclear reactor vessels, PCRV's.

It was shortly after I joined the Institute for Statics and Dynamics, ISD, at the Aeoronautical and Aerospace Department of the University of Stuttgart when we faced the need to assess the triaxial strength of concrete. At that time, the ISD was known for the early contributions to finite elements under the direction of John Argyris, and the development of the general purpose program ASKA. This innovative software platform featured an extensive element library, multilevel substructure capabilities, and a sophisticated data base management system to

* K. J. ウィラム/University of Colorado at Boulder process thousands of degrees of freedom through a direct Cholesky solver (using a hypermatrix scheme which partitions the structural stiffness matrix into the $64 \mathrm{~Kb}$ memory of a CDC 6600 computer). I had just completed my Ph.D. degree under Alex Scordelis at the University of California Berkeley on some intricate development of finite elements with drilling degrees of freedom for modeling box girder bridges, when I arrived in Stuttgart to head a project on the analysis and design PCRV's. The objective was to develop a finite element program for the analysis of a high temperature reactor of which a HTR 1:5 scale model was being tested by Krupp Hochbau with significant funding by the German federal government. I vividly remember the argument of Professor Schlaich at the University of stuttgart, who compared the challenges of prestressed concrete reactor pressure vessels with traveling to the moon in aerospace engineering. During the final phase of my dissertation work at UC-Berkeley I did benefit from listening to the 3-dim finite element developments of Joe Rashid at Gulf Atomic/San Diego, who presented very impressive finite element simulations of a high temperature reactor containment vessel in the UCBerkeley series of structural seminars.

Right after my arrival at ISD-Stuttgart we undertook a crash program to incorporate a family of quadratic displacement elements into SMART, a special purpose program for Structural Mechanical Analysis in Reactor Technology based on ASKA. In the first stage we incorporated a suite of finite elements for the 3-dim modeling of curvilinear prestressing cables, liner membranes and solid hexahedral and pentahedral solid concrete elements. The main limitation however were the linear elastic restrictions of the original finite element program. In context of the 1:5 HTR model simulations the immediate questions arose, (a) what is the limit load capacity of the pressurized vessel, and (b) what is its Iongterm service load performance considering creep 
and relaxation as well as thermal heating and cooling cycles and their interaction with hygral shrinkage effects.

\section{Triaxial Concrete Strength}

To start with, we examined different failure criteria for concrete materials which were used at that time. Thereby, the traditional approach of strength of materials was to probe demand versus resistance with the aid of a limit state condition using the geometrical concept of the MOHR envelope condition.

The geometrical interpretation of the triaxial strength hypothesis $F(\sigma)=0$ centers around the osculation of the major circle of stress and the failure envelope of the material. Thereby, the location of the osculating point $\mathrm{P}$ defines the critical combination of normal and shear tractions $\sigma, \tau$ on the failure plane $\theta$ $= \pm \theta_{c r}$, and the orientation determines the mode of failure. In other terms, the MOHR envelope in Figure 1 does not only tell us when failure takes place, but it also furnishes the governing mode of failure, although without kinematic desription. The main draw-back of the MOHR failure envelope is its independence on the intermediate principal stress since the radius of the major stress circle is governed by $r_{\max }=\frac{1}{2}\left|\sigma_{1}-\sigma_{3}\right|$.

At the beginning of the 1970's most accepted triaxial strength criteria for cohesive-frictional materia Is were based on the pressure-dependent shear stress conditions of MOHR-COULOMB, and the maximum normal stress condition of RANKINE for tensile cracking. Combination of the two resulted in a hexagonal pyramide of the failure envelope augmented by tension cut-off's in the principal stress space. $C^{0}$ continuity of the failure envelope included folds and corners both in the hydrostatic as well as deviatoric sections. We adopted this multi-facetted failure envelope to perform nonlinear finite element

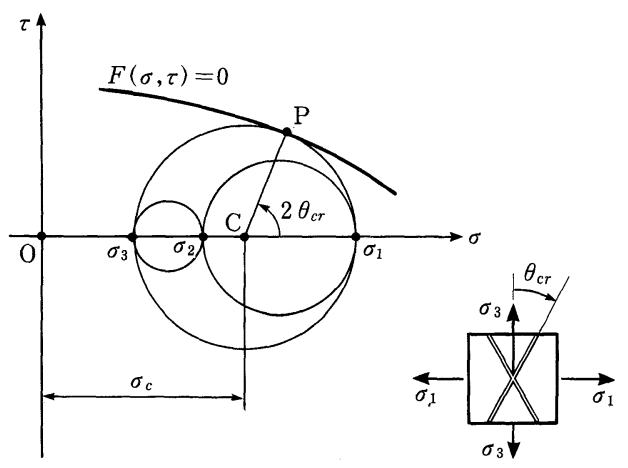

Figure 1: MOHR Concept of Universal Failure Envelope. failure studies on the HTR 1:5 scale model and on reinforced concrete reactor closures using difFerent stress redistribution strategies to return excess overstresses back to the failure envelope.

The inherent difficulties with the folds and corners of the Mohr-Coulomb failure envelope with tension cut-off's, together with the lack of a rational constitutive formulation led us to search for a $C^{1}$ continuous failure envelope with continuous tangent planes and normals thereof. I was fortunate to share an office with Karl Pister, University of California Berkeley, who spent a sabbatical year in 1973 at the ISD-Stuttgart. He pointed me to his earlier work on a two invariant formulation of concrete strength under combined stresses, which had been published by Boris Bresler and Karl Pister in the Journal of ACI, 1958. It was at that stage that I recognized the importance of the third invariant and its geometric interpretation in terms of the angle of similarity $\theta$ in the HaighWestergaard coordinates, $\xi, \rho, \theta$. Considering triaxial concrete data on cylindrical test specimens available at that time, it was apparent that the failure envelope of an isotropic material needs to be characterized by three independent variables, e.g. the three principal stresses or the three principal invariants or any combination thereof.

$$
\begin{aligned}
& F(\sigma)=0 \text { isotropic } F\left(I_{1}, I_{2}, I_{3}\right)=0, \\
& \text { or } F(\xi, \rho, \theta)=0
\end{aligned}
$$

Figure 2 reproduces some of the classical triaxial concrete data that demonstrate a very noticeable effect of the third stress invariant along the compressive and tensile meridians $\theta=60^{\circ}$ and $\theta=0^{\circ}$.

Subsequent triaxial test programs on concrete materials in France, Germany, Netherlands Japan and the USA verified the very different strength and

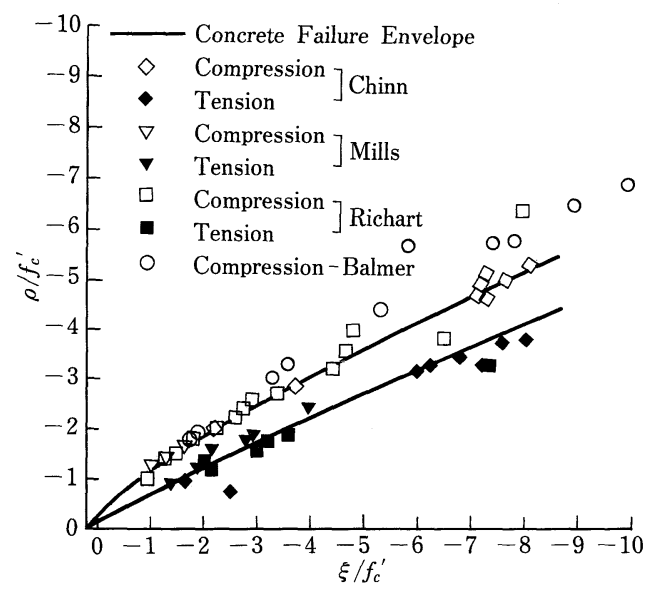

Figure 2: Triaxial Test Data along Compression and Extension Meridians. 
failure modes in triaxial compression and triaxial extension, see e.g. Kurt Gerstle et al, CU-Boulder, 1983, and Jan van Mier, TU Delft, 1984. From these observation, it was a small step to generate a smooth failure surface using as guiding principle that the envelope should be convex. Decomposing the geometric construction of the failure envelope into deviatoric and hydrostatic sections, it was apparent that the argument of isotropy leads to three-fold symmetry around the liydrostat, actually the symmetry is six-fold if one includes the mirror images along the positive and negative meridianal planes of principal stress. Therefore, the issue boiled down to the construction of the transition of shear strength from the compressive to the tensile meridian in terms of an elliptic sector which satisfies normality at the planes of six-fold symmetry and which thus maintains $C^{1}$ continuity among the adjacent sectors. The ellipse was chosen rather than a cubic spline approximation to assure convexity for all angles $0 \leq \theta \leq 60^{\circ}$. In Spring 1974, I was privileged to present the details of the elliptic approximation of the deviatoric section and its implementation into an elastoplastic material model at the IABSE-Seminar on 'Concrete Structures Subjected to Triaxial Stresses' hosted by ISMES, Bergamo Italy. The written paper was dedicated by my co-worker Peter Warnke and myself to the 60 th birthday of John Argyris, the 'Prof' at ISD. The manuscript appeared in Report 19 of IABSE-Zurich [1975]. In spite of being published in rather obscure seminar proceedings the 'Five Parameter Model' turned out to be one of my most widely cited publications which made its way into several commercial finite element codes. It found wide distribution also because of its dissemination in the popular text books by Wai-Fah Chen, Plasticity in Reinforced Concrete, 1982, and Plasticity for Structural Engineers, 1988. An intriguing twist of the original formulation was introduced in the polish Ph.D. dissertation of Marek Klisinski 1985, who normalized the out-of-roundedness of the elliptical trace in the deviatoric section in terms of the eccentricity parameter $e=r_{t} / r_{c}$. This leads to the convenient definition of shear strength in terms of radial distance from the hydrostatic axis,

$$
\begin{aligned}
& r(\theta, e)= \\
& \frac{4\left(1-e^{2}\right) \cos ^{2} \theta+(2 e-1)^{2}}{2\left(1-e^{2}\right) \cos \theta+(2 e-1) \sqrt{4\left(1-e^{2}\right) \cos ^{2} \theta+5 e^{2}-4 e}}
\end{aligned}
$$

where the eccentricity $0.5 \leq e \leq 1.0$ is in general a function of hydrostatic stress. Thus the dependence of the radial distance on the third invariant $\theta$ allows the deviatoric trace to expand from triangular to circular shapes with increasing hydrostatic pressure.

As mentioned earlier on, the curvilinear shape of the failure envelope is a function of the three invariants of stress and/or deviatoric stress, $I_{1}=\operatorname{tr} \sigma, J_{2}=\frac{1}{2} \mathrm{~s}: \mathrm{s}$, $J_{3}=\operatorname{det}(s)$ that are related to the Haigh-Westergaard coordinates by $\xi=\frac{1}{\sqrt{3}} I_{1}, \rho=\sqrt{2 J_{2}}$, and $\theta=$ $\frac{1}{3} \cos ^{-1}\left(\frac{3 \sqrt{3}}{2} \frac{J_{3}}{J_{2}^{1.5}}\right)$. The volumetric dependence of the original model was described originally by two quadratic parabolas, one for the compressive and one for the tensile meridian, which intersect at the vertex of eqvitriaxial extension. This led to six parameters minus one constraint condition, which was the reason for the name of the five parameter model. In the absence of test data in very high confined compression we originally recommended to extend the conical surface into a von Mises cylinder when the shear strength of the tensile meridian reaches that of the compressive meridian. At a later stage we recognized the need to change the parabolic variation of the hydrostatic sections which resulted in the 'Extended Leon Model' of Guillermo Etse and Kaspar Willam, ASCE Journal of Engineering Mechanics, 1994, and the 'three parameter model' for triaxial concrete strength by Philippe Menétrey and Kaspar Willam, Structures Journal of ACI, 1995. The most recent development at CU-Boulder included a hardening cap which led to the construction of the failure envelope by Hong Kang and Kaspar Willam, ASCE Journal of Engineering Mechanics, 1999, in the form of the

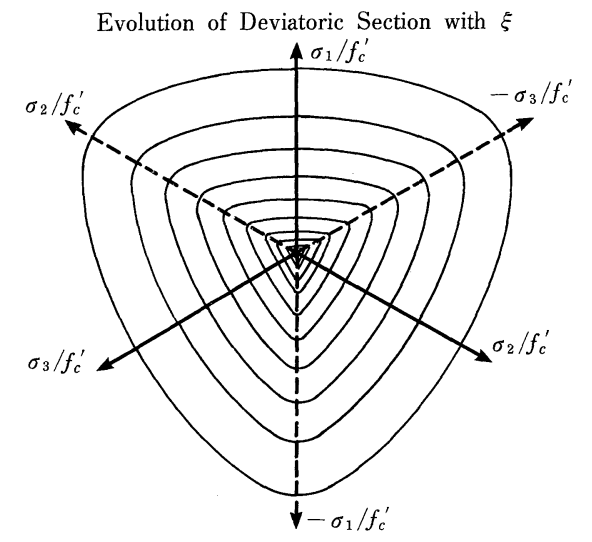

Figure 3: Five Parameter Model, Deviatoric Sections, Willam \& Warnke [1975]. 


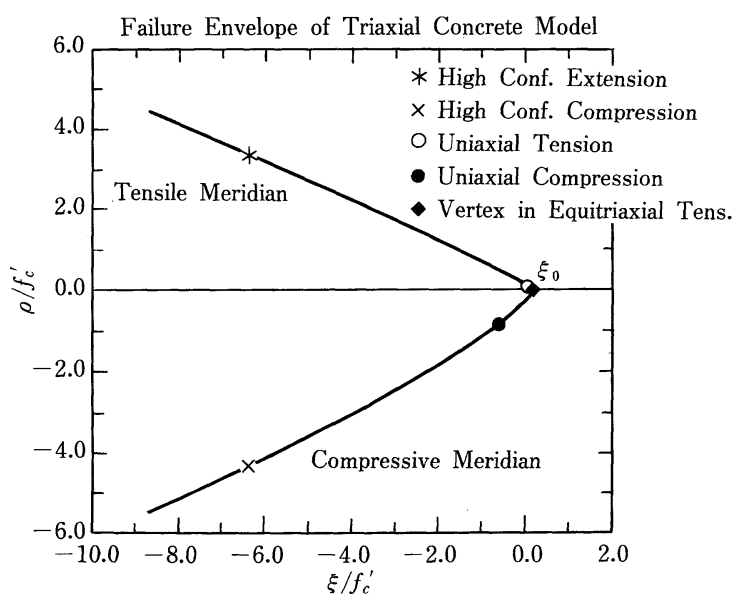

Figure 4: Three-Invariant Concrete Model, Tensile and Compressive Meridians, Kang \& Willam [1999].

curvilinear conical surface depicted in Figure 4. The meridianal sections describe a non-axisymmetric paraboloid which is $C^{1}$-continuous except at the vertex.

$$
F(\xi, \rho, \theta)_{\text {fail }}=\frac{\rho r(\theta, e)}{f_{c}^{\prime}}-\frac{\rho_{1}}{f_{c}^{\prime}}\left(\frac{\xi-\xi_{0}}{\xi_{1}-\xi_{0}}\right)^{\alpha}=0
$$

The order of the power function, and thus the shape of the meridian was determined as $\alpha=0.77$ by fitting the triaxial concrete test data of Launay and Gachon, 1972. solving $F\left(\xi_{u c}, \rho_{u c}, \theta_{u c}, \rho_{1}\right)=0$ for the shear strength yields $\rho_{1}=\frac{\rho_{u c}}{\left(\frac{\xi_{u c}-\xi_{0}}{\xi_{1}-\xi_{0}}\right)^{\alpha}}$. This assures that the compression meridian passes through the point of uniaxial compressive strength, $F\left(\xi_{u c}, \rho_{u c}, \theta=60^{\circ}\right)$, where the subscript $u c$ indicates uniaxial compression. The triaxial concrete model is delimited in tension by the uniaxial tensile strength at $\xi_{0}=\sqrt{3} f_{t}^{\prime}$, and by two parameters which define the shear strength of the compressive and tensile meridians under high confinement. The hardening cap is not shown in this figure since it opens up and approaches the conical failure envelope in an asymptotic fashion.

\section{Failure Analysis}

Although the original envelope concept of Otto Mohr determines the failure mode, it does not specify the mechanism and its kinematic manifestation. It is left to the individual to determine whether failure initiation leads to sudden collapse in the spirit of perfectly brittle behavior without redistribution capacity, or whether failure is governed by plastic flow based on some notion of limited or unlimited ductility. In reality, concrete like many other cementbased materials are brittle in tension and very ductile in confined compression. It is this brittle-ductile transition which challenges failure analysis in a profound manner. It results in model predictions that strongly depend on the degree of confinement, i.e. on the restraint of dilatancy which controls the REYNOLDS effect of volumetric expansion under shearing. Thereby, it is understood that failure envelopes are the natural geometric constructs of loading and potential surfaces in hardening/softening constitutive formulations based on yield conditions and inelastic evolution equations.

\section{Conclusion}

These reminiscences summarized the curious history behind the development of the triaxial failure envelope for concrete materials known under the name of the 'Five Parameter Model'. Many important topics could not be covered for the sake of brevity, most notably the role of elastoplastic localization analysis to determine the mode of failure, the issue of size and gradient effects in softening, and last but not least, the computational aspects of failure analysis with finite elements.

\section{References}

1) Etse, G. and K. Willam: 'A Fracture energy-based constitutive formulation for inelastic behavior of plain concrete.' $A S C E$ Journal of Engineering Mechanics, Vol.120, pp.1983-2011, 1994

2) Kang, H. \& K. Willam: 'Localization characteristics of a triaxial concrete model.' ASCE Journal of Engineering Mechanics, Vol. 125, pp.941-950, 1999

3) Menétrey, $\mathrm{Ph}$. and $\mathrm{K}$. Willam: 'A triaxial failure criterion for concrete and its generalization.' ACI Structures Journal, Vol. 92, pp.311-318, 1995

4) Willam, K.J. \& E.P. Warnke: 'Constitutive model for the triaxial behaviour of concrete.' Proc. Intl. Assoc. Bridge Structl. Engrs, Report 19, Section III. Zürich, Switzerland. pp.1-30, 1975

\section{コンクリートの 3 次元応力場の破壊則}

1. はじめに

3 次元応力場における破壊則は, 鉄筋コンクリート構
造物，あるいはプレストレストコンクリート構造の安全 性の評価に際しては最も基本的必要データである。許容 応力度設計法であっても, 許容応力度状態がどれくらい 
破壊基準から離れているかによって安全性を評価してい るのであって，この場合でむ破壊基準は基本的なデー夕 といえよう。破壊則は材料の歪み, 応力, あるいはネル ギーの許容量を定めることに使用されているのである。 一方，LRFD設計法では，降伏関数で現される破壊局 面を材料の限界值として用いている。耐震設計のように 変形の限界值で破壊を表現する必要がある場合もあるが, 破壊則が近代の構造設計一信頼性設計において中心的な 課題であることは間違いないことである。

\section{2. 歴史的な回顧}

これから述べることは，一般的に Five Parameter Model と称されている 3 次元破壊則の構築に関わる回 顧談であるが，Five Parameter Model は，1970 年代当 初に，プレストレストコンクリート原子炡容器, PCRV の限界状態設計法用にあたって筆者らが開発したもので ある。コンクリートの 3 次元破壊則の構筑と言う問題に 直面したのは, 私が Stuttgart 工科大学の航空宇宙学科 の力学研究所 (Institute for Statics and Dynamics) に参加した直後であった。当時, Stuttgart工科大学の 力学研究所 (以後, ISD と呼ぶ) は, John Argris 教 授の FEM 解析に関する研究，そして汎用プログラム ASKA の開発で知られていた。汎用プログラム ASKA は, $64 \mathrm{~Kb}$ の容量である $\mathrm{CDC} 6600$ 計算機用で数千自由 度の剛性マトリックスを hypermatix スキームを用いて choresky 分解し, 逆行列をつくる高度なデータ管理シ ステム, 多水準の構造部分分割法, 多彩な要素ライブラ リー等で特徴づけられていた。私がこの PCRV の設計 および解析プロジェクトのヘッドとして Stuttgart に赴 任したのは，ちょうどUC Berkeleyで Alex Scordelis の所において箱げた橋のモデル化における内部自由度の 複雑な問題で学位論文を書き終えたばかりの時であった。 このプロジェクトの目的は, 高温原子炉 HTR の $1 / 5$ モ デル実験，これはKrupp Hochbau で実験が成されたの であるが，に対して有限要素法解析のプログラムを作成 することであった。そして，これらのプロジェクトに対 して, ドイツ連邦政府から多額の研究予算が割り当てら れていた。私は今でも覚えているが, 同じ大学の Schlaich 教授が，このプロジェクトは, 航空宇宙工学 の月面旅行プロジェクトと同じだと言っていた。UC Berkeleyにおける学位論文作成の最終局面において, San Diego の Gulf Atomic 社の Joe Rashid の 3 次元有 限要素法の開発に関する研究の話を聞いて, 大変得ると ころがあったことも記憶にある。彼は，高温にさらされ る原子炉格納容器の有限要素シミュレーションを UC Berkeley の構造セミナーでシリーズ的に講演していた。

ISD-Stuttgart に着くやいなや，ASKA の一部分で ある SMART (Structural Mechanical Analysis in Reactor Technology）の中に一連の 2 次の補間関数を
用いた要素を用いたクラッシュプログラムの開発に着手 した。最初のステージでは曲線状のプレストレッシング ケーブルの曲線要素, 面ブレーンなどの面要素, 6 面体 および 5 面体立体要素の要素モデルなどを組み込んだ。 しかし, 主たる問題はメインのプログラムが線形弾性体 向けであり, 先に述べた高温原子炉 HTR の $1 / 5$ モデル 実験のシミュレーションで, 直ちに起こってきた問題は, （a ）圧力容器の限界荷重は何であるか，（b）加熱・冷 却の繰り返しを受け，かつ水和反応が進行している間で の使用状態での経年変化はクリープ, リラクゼーション を考慮した場合にどうなるかということであった。

\section{3 次元応力場でのコンクリート強度}

上記の問題を解決するために，我々は当時使われてい たいくつかの破壊基準を検討してみた。当時一般的に材 料の強度として用いられていたのは，モールの応力円が 強度包絡線内にあることを確かめることであった。

3 次元強度 $F(\sigma)=0$ は，この破壊局面にモールの応 力円が接することにより定まる，とされていた。そして, 接触点 $P$ は, 限界応力 $(\sigma, \tau)$ の 1 組を $\theta= \pm \theta_{c r}$ の平面 上で与え，かつその方向は破壊のモードを定めるという ものであった。端的にいうなら，モールの破壊局面は破 壊の開始点を定義するだけではなく，破壊モードまで定 義するというものであった。むっとも，破壊の運動学的 な定義は与えはしないのであるが。この破壊の定義の 欠点は, 主たる応力円が $r_{\text {max }}=\frac{1}{2}\left|\sigma_{1}-\sigma_{3}\right|$ で与えられ るから，モールの破壊包絡線は中間主応力に関係しない ことであった。1970 年代の初頭，粘着性摩擦材料の 3 次元強度としては，モール・クーロンの圧力依存型せん 断応力と, 引張ひび割れを生じさせる Rankin の最大主 応力で屯って表現されうると考えられていた。そして, この 2 つの基準は主応力空間において, tension cuttoff を持った 6 角柱として与えられる。破壊局面は $C^{0}$ 連続で, 面とコーナーを静水压軸を含む面ばかりでなく 偏差平面にも含む。我々は，この破壊面を用いて HTR の $1 / 5$ モデル，および鉄筋コンクリート原子炉開閉部の 非線形解析を行った。Tension cutt-off のある MorhCoulomb 破壊局面の使用の困難さ，ならびに妥当性を 欠いた構成則使用に直面して，我々は連続な接平面なら びに方向余弦を保証する $C^{1}$ 連続な破壊局面を検討する ことになった。ここで幸いだったのは，UC Berkeley の Karl Pister が 1973 年サバティカルで ISD Stuttgartに来ており同室だったことである。複合応力 下に打けるコンクリート強度の 2 不変量による表現を行っ ている彼と Boris Blesler の論文（ACI 1958 年）を紹 介してくれたのである。この時に, 私は初めて第 3 不変 量の重要さ，すなわち Haugh-Westergaard 座標（ $\xi, \rho$, $\theta$ ）におけるシミラリティ角度 $\theta$, の重要性ならびにそ 
の幾何学的な意味を認識した。当時集めることが可能で あった 3 次元の円柱供試体のデー夕を検討してみると等 方体としてのコンクリートの破壊は，3個の不変量ある いは 3 個の主応力, あるいはそれらの関数で特徴づけら れなくては成らないのは明らかであった。

$$
\begin{aligned}
& F(\sigma)=0 \text {, 等方体の場合 } F\left(I_{1}, I_{2}, I_{3}\right)=0 \text {, } \\
& \text { または } F(\xi, \rho, \theta)=0
\end{aligned}
$$

図-2 は, 当時集めたデータであるが，3 次元コンリー 卜強度が第 3 不変量に依存していることを明暸に示して 打り压縮子午線 $\theta=60^{\circ}$ 之, 引張り子午線 $\theta=0^{\circ}$ 周りの データである。その後引き続いて 3 軸試験が, フランス, ドイツ, オランダ, 日本, 米国で行われ 3 軸圧縮と 3 軸 引張りとでは, 破壊のモードが大きく変化することがわ かってきた（Kurt Gerstle et al. CU Boulder, 1983, Jan van Mier, TU Delft, 1984 参照)。これらの考察から外 に凸であることを条件として，スムースな破壊局面を構 築するのは，僅かなステップでしかなかった。破壊局面 を偏差平面と静水圧平面とに分けて構成すれば，等方体 であることから, 静水圧軸周りに 3 軸対称となり, むし 鏡像対称も含めれば 6 軸対称となるのは明らかであった。 したがって, 残された問題は圧縮子午線から引張り子午 線への $\theta$ 変化に伴うせん断強度を, 6 軸対称面での直交 性を保ちながら, したがって隣接区域との境界で $C^{1}$ 連 続性を保証しながらいかに構筑するかであった。 $0 \leq \theta$ $\leq 60^{\circ}$ の間で面の凸性を保証するために, Spline 関数近 似よりも, 楕円近似を選択した。1974 年の春, 私はイ タリア Bergamo の ISMES が主催した “3 軸応力を受 けるコンクリート構造物” に関する IABSE セミナーに おいて偏差平面上の楕円近似と材料モデルへのその応用 と題する講演を行った。この論文は, 私と Peter Warnkeによって, ISD の教授である John Agiris の 60 歳の誕生記念として, 提出され, IABSE-Zurick, Report-19に納められている。比較的に目立たないセミ ナーで公表されたにもかかわらず，このFive Parameter Model は私の論文の内最も引用度の高い論 文の一つであり, いくつかの市販の有限要素プログラム の中に取り入れられている。また, Wai-Fah Chen の 著書 “Plasticity in Reinforced Concrete, 1982", “Plasticity for Structural Engineers, 1988”に紹介さ れて，広く知られるようになった。そしてその後，ポー ランドにおいて Marek Klisinski が 1985 年学位論文の 中で, 偏差平面上のパラメター $e=r_{t} / r_{c}$ を用いて破壊局 面の正規化表示を行い, 次の偏差平面上のせん断強度式 が導かれた。

$$
\begin{aligned}
& r(\theta, e)= \\
& \frac{4\left(1-e^{2}\right) \cos ^{2} \theta+(2 e-1)^{2}}{2\left(1-e^{2}\right) \cos \theta+(2 e-1) \sqrt{4\left(1-e^{2}\right) \cos ^{2} \theta+5 e^{2}-4 e}}
\end{aligned}
$$

ここで, 偏差パラメータ $0.5 \leq \boldsymbol{e} \leq 1.0$ は, 一般に静水圧
の関数である。このようにして, 偏差平面の半径方向の 距離 $(\theta$ の関数) は, 静水压の増加に伴って三角形から 円形へと拡大変形していくことになる。

最初に述べたように, 破壊局面の局面は, 応力あるい は偏差応力の 3 つの不変量 $I_{1}=t r \sigma, J_{2}=\frac{1}{2} \mathrm{~s}: \mathrm{s}$, $J_{3}=\operatorname{det}(s)$ あるいは，その間数である HaighWestergaard の座標 $\xi=\frac{1}{\sqrt{3}} I_{1}, \rho=\sqrt{2 J_{2}}$, そして $\theta=$ $\frac{1}{3} \cos ^{-1}\left(\frac{3 \sqrt{3}}{2} \frac{J_{3}}{J_{2}^{1.5}}\right)$ でむって表される。静水圧の影響 は元々の式では，二つの 2 次曲線で表されていた。一つ は，压縮子午線であり，一つは引張り子午線である。そ してそれらは, 等引張り軸上で交差している。これは, 2 本の 2 次曲線の係数である 6 個引く交差条件 1 個から, Five parameter Model という名称が付いた理由である。 我々は当初, デー夕が不足していたところから非常に大 きな压縮領域では角錐状から Von Mises の円錐状へと 移行する局面を提案していた。しかし，その後静水压面 上での 2 次放物線を変えて, 拡張 Leon Modelo を提案 することになる (Guillermo Etse, and Kaspar Willam, ASCE Journal EM, 1994)。そして Three Parameter Model (Philippe Menetrey and Kaspar Willam, Stryctures Journal ACI, 1995)。最新の発展は, 円錐 状の硬化キャップを持った破壊局面である（Hong Kang and Kaspar Willam, ASCE EM., 1999)。子午面 は非対称の 2 次放物線で頂点以外は $C^{1}$ 連続である。

$$
F(\xi, \rho, \theta)_{\text {fail }}=\frac{\rho r(\theta, e)}{f_{c}^{\prime}}-\frac{\rho_{1}}{f_{c}^{\prime}}\left(\frac{\xi-\xi_{0}}{\xi_{1}-\xi_{0}}\right)^{\alpha}=0
$$

べき状関数のべき $\alpha$ は, Launay and Gachon, 1972 年 のデータから， $\alpha=0.77$ としている。

$$
F\left(\xi_{u c}, \rho_{u c}, \theta_{u c}, \rho_{1}\right)=0
$$

を解いて, $\rho_{1}=\frac{\rho_{u c}}{\left(\frac{\xi_{u c}-\xi_{0}}{\xi_{1}-\xi_{0}}\right)^{\alpha}}$ を得るが，これは压縮子午

線が 1 軸压縮強度点 $F\left(\xi_{u c}, \rho_{u c}, \theta_{u c}, \rho_{1}\right)=0$ を通ること を保証している。ここで, 下付の添え字 $u c$ は 1 軸圧縮 を意味している。さらに, 3 軸引張り強度は, 1 軸引張 り強度 $\xi_{0}=\sqrt{3} f_{t}^{\prime}$ で区切られるとともに, 3 軸の高圧縮 応力度領域では 2 つのパラメターで定義される。この図 の中では硬化キャップは, 段々開いていき円錐状の包絡 局面に漸近していくので描かれていない。

\section{4. 破壊解析}

Otto Mohr の破壊概念は破壊モードを定義し得たが， そのメカニズムや破壊時の運動学的挙動を記述していな い。破壊が完全なぜい性的であるか，あるいはじん性を 伴った塑性的なものであるかの判断は，それぞれの技術 
者に任されていた。コンクリートの実際は，他のセメン 卜系材料之同様に引張りではぜい性的であり, コンファ イン効果のある圧縮応力下では, じん性的である。この, ぜい性性からじん性性への変化が, 破壊解析に奥深い影 響を及ぼす。したがって，解析結果はコンファイン効果 の程度に依存すると同時にせん断変形下での Reynolds 効果（体積変化）の拘束の程度に依存している。破壊局 面の構築とは従って, 非弾性発展則と降伏条件に基づく 硬化ならびに軟化の構成則定式化の過程における載荷局 面, ポテンシャル局面の自然な幾何学的な構築の行為で
あるといえよう。

5. 結論

この回顧は, Five Parameter Model という名で知ら れているコンクリート 3 次元破壊局面の開発・発展の背 後の歴史的な経緯を示している。この文章の中では, ペー 㳊数の制限から, 破壊モードを決定する弾塑性局所化解 析や, 軟化に伴う歪み勾配効果, 寸法効果, そしてまた 有限要素法による数值解析的な面について触れ得なかっ たが，いつか，また触れ得る機会を持ちたい。

\section{国際会罣一フー}

\section{International Conference on Performance of Construction Materials in the New Millennium \\ A New Era of Building}

\section{日 時: Feb. 18-20, 2003 \\ 場 所 : Cairo, Egypt}

Performance criteria for different building materials have recently been recognized as suitable design requirements. Many building codes are moving towards requirements governed by the performance of the material in the proposed area of use rather than meeting specific prescribed property values. New building materials have been developed and some conventional materials have proved to lack durability. The consequence is a change in the philosophy of material testing from testing the material properties to testing the material performance under realistic service conditions.

The aim of this conference is to provide an international forum for those who are interested in the performance of construction materials. A forum to express the need of our construction materials to meet appropriate performance criteria. The conference will bring researchers, industrial consultants, contractors and material producers together to discuss and exchange information and experience. The outcome will be a sound foundation for the research and development of construction materials in the new millennium.

The conference scope is directed but not limited to the following items

- Performance criteria for construction materials and techniques including

- Concrete and Masonry

- Steel

- Repair materials

Pavemant materials

- Performance of new construction materials including

- Admixtures

- Advanced composite materials (e.g. FRP)

\section{Special concretes}

- Performance assessment of materials and structures

- New testing methods

- New acceptance criteria

- Performannce requirements of historical structures

- Performance based design

- Performance prediction models of materials and structures

- Case studies where unconventional performance criteria were required.

- Quality control and quality assurance

\section{Call for Papers:}

The International Conference on Performance of Construction Materials in the New Millennium will be held in Cario, February 18-20, 2003. Interested authors are invited to submit an abstract of 200-300 words (preferably by e-mail) to: Dr. Mahmoud Reda Taha

Department of Civil Engineering

The University of Calgary

2500 University Dr., N.W., Calgary

Alberta T2N 1N4, Canada

Tel: (403)716-8042, Fax: (403)282-7026

e-mail: icpcm@ucalgary.ca

\section{Key Deadlines:}

- Abstract due date: January 15, 2002

- Acceptance and notifications to authors: March 15, 2002

- Submission of manuscript (camera ready): May 15, 2002

- Acceptance of proposed manuscripts: August 15, 2002

- Submission of final manuscripts: October 15, 2002

\section{Additional Information:}

For futher information please visit the conference web site http://www.ucalgary.ca/ icpcm 